\title{
Resource-saving environmentally friendly technologies and waste processing as a key to improve the sugar beet production efficiency
}

\author{
Ivan Saltyk*, and Yulia Bolokhontseva \\ ${ }^{1}$ Kursk State Agricultural Academy named after Prof. I.I. Ivanov, 70, Karl Marx street, Kursk, 305021, Russia,
}

\begin{abstract}
The world experience shows that in the 21st century, the sustainable development of the Russian beet production and sugar industry is impossible without scientific achievements. It requires low-cost resource-saving technologies that can save resources and increase the efficiency of sugar beet production. It was found that in order to increase the profitability of the sugar beet production industry, the following technologies should be used: intensive (application of herbicides); resource-saving (strip post-emergence application of herbicides); environmental protection (production of beets without herbicides, but with the use of manual labor). The intensification of sugar beet processing entails the use of new technologies that can reduce the volume of waste. The waste-free production makes it possible to strengthen the role of secondary resources as raw materials in the manufacture of various products. Secondary raw materials are used as raw materials. Structural and investment policies pursued by the government do not stimulate their processing. Therefore, beet-sugar agro-associations themselves should solve these issues. Their efforts should be aimed at ensuring the comprehensive processing of sugar beets to produce high-quality valuable food and feed products from production waste.
\end{abstract}

\section{Introduction}

Sugar beet (Beta vulgaris L.), commonly considered as a temperate region crop, is grown in subtropical countries even during the winter season. It has a growing season about half that of sugar cane. Its yield and quality are influenced by various environmental and agronomic factors: varieties, sowing time and density, sowing depth, etc. [1].

Parasitic weeds are a serious agricultural problem. Studies show that about 20 families (3000-5000 species) of higher plants are parasites [2].

In recent decades, agricultural enterprises have tested various technologies for growing, weed control and harvesting sugar beets. In Tambov, the VIITI Institute developed a new technology for the cultivation of sugar beets using energy-intensive tractors VT-100 and LTZ155, which were aggregated with an 18-row machine produced by OKB "Soyuz".

In 2001, the Russian Agricultural Academy developed a concept of the technical development of machine technologies and means of mechanization of sugar beet production, which entailed the development of new technologies for the cultivation of this crop. The main task was to combine operations and reduce their number. Other parameters were also observed [3].

The All-Russian Research Institute of Sugar Beet and Sugar suggested increasing the profitability of the beetgrowing industry by using new technologies such as:
- the intensive technology, which involves sowing at the final density and continuous application of herbicides;

- the resource-saving technology, which involves sowing at the final density of plantings and strip postemergence application of herbicides;

- the environmental protection technology, which involves the production of beets without herbicides, but the use of manual labor [4].

At the turn of the XX-XXI centuries, Ukrainian agricultural enterprises grew sugar beets on an area of about 80 thousand hectares using the intensive and energy-saving technologies. The methods increased productivity, saved resources and ensured the environmental safety.

The integrated approaches to technological processes involved the rational use of material resources, new machines and highly productive varieties and hybrids (Pyrkin, 1998). These issues have been widely discussed in the scientific literature $[5,6,7,8,9,10,11,12]$.

To improve the efficiency of the sugar beet production, it is necessary to use sugar beet production technologies for receiving raw materials, storing and processing sugar beet. The technology has been developed by PPO "Sugar", Ukrsveklosakharagroprom and other companies. It was applied in 1976-1980 by Mironovsky, Salivonkovsky, Gonorovsky, VelikoOktyabrsky, and Gubinikhsky sugar factories. The

\footnotetext{
Corresponding author: saltyk46@ rambler.ru
} 
technology was recommended for the widespread implementation [13]

\section{Problem Statement}

A lot of scientific works are devoted to the issue of creating a free food market. Researchers have been developing methods aimed to improve the economic efficiency of the beet-sugar industry. However, there are no solutions to the issues of efficient operation of beetgrowing farms and sugar factories, which are experiencing the onslaught of large foreign, national and regional companies. New methods are required for assessing the efficiency of sugar factories and beetgrowing farms using resource-saving, environmentally friendly technologies. The issues of innovative secondary processing of production waste are understudied.

\section{Research Questions}

The research subject is regularities of the development of beet-growing farms and sugar factories: implementation of resource-saving, environmentally friendly technologies and beet-sugar production waste processing, production of food and feed products from production waste.

\section{Purpose of the Study}

The article aims to study the development and implementation of resource-saving, environmentally friendly technologies in the sugar beet industry and production waste processing technologies.

\section{Research Methods}

The theoretical and methodological basis is studies on agricultural economics. The systematic approach and the dialectical cognition made it possible to study patterns and processes of development in interrelation and interdependence.

A number of general scientific and special methods were used (economic, mathematical and statistical).

\section{Findings}

To increase the efficiency of the technologies, they must be adapted to each agricultural enterprise. Computer expert systems that accumulate practical experience and skills of highly qualified specialists will help to do this. Expert systems and other information technologies can be used by farms and zonal scientific and technical centers that monitor the state of soils, select highly productive and disease-resistant varieties and hybrids, monitor technological qualities of root crops, dealer services, machine-technological stations (MTS) [14].

According to A.V. Kornienko, A.K. Nanaenko, the following sugar beet production technologies should be developed: low-cost technologies saving resources (basic); advanced intensive technologies based on scientific developments and saving resources [14].

Interesting sugar beet production experience has been accumulated by Northern Germany. In German beet fields, ridges are cut with a height of about $20 \mathrm{~cm}$. At the top, their width is about $13 \mathrm{~cm}$. Beets are sown simultaneously with the formation of ridges. The soil is lifted by the rotary cultivator and the ridges are created by the driven ridge roller. This method compacts the soil surface, which allows its shape to remain unchanged until the beginning of harvesting. Compared to the traditional sugar beet cultivation methods, the German method results in faster evaporation of water in the soil and a faster rise in soil temperature. Sugar beets are harvested with conventional six-row beet harvesters.

The most important direction in the development of the sugar beet industry is the development of new energy-saving technologies to process raw materials without waste.

This issue is dealt with in a large number of scientific works [15, 16, 17, 18, 19, 20, 21, 22, 23, 24, 25, 26, 27].

The need to improve the efficiency of sugar beet production imposes requirements on processing enterprises aimed at saving resources when recycling production waste. Peculiarities of the beet processing technology make it possible to have large sources of secondary raw materials. The annual volume of beet sugar production waste is about 60 million tons [28].

With an average sugar yield of $10-12 \%$ to the mass of processed beets, there are about $83 \%$ of fresh beet pulp and $5.4 \%$ of molasses; $12 \%$ fall on the filtration sludge, $15 \%$ - on the conveyor-washing sludge, $1.4 \%$ on the limestone sifting, up to $350 \%$ - on sewage, about $3 \%$ - on tails.

The sugar beet processing intensification entails the use of new technologies that ensure a minimum amount of waste. The waste-free production makes it possible to strengthen the role of secondary resources as raw materials in the manufacture of various products [4].

Unfortunately, secondary raw materials are used mainly as raw materials. The structural and investment policies pursued by the government do not stimulate the processing of secondary raw materials. Therefore, these issues should be solved by the sugar beet agricultural associations. Their efforts should be aimed at processing sugar beets to produce high-quality food and feed products from production waste.

HRV and waste are used irrationally. Only $10 \%$ of beet pulp are dried, about 35\% are fed to animals fresh, the rest is used as an acidic product. At the same time, beet roots lose up to $50 \%$ of nutrients, which impairs their quality. Molasses is mainly used to produce alcohol. However, it contains many valuable substances: sucrose, lactic and acetic acid, glutamic and betaine amino acids, and other beneficial nutritional components.

Sugar production waste is used inefficiently (filter cake, crumble and beet tails, limestone screening, pulp press and waste water).

Only a small part of the filter cake is used as a fertilizer and for alkalizing acidic soils. Its main mass is directed to filtration fields, and settles in dumps, 
occupies large areas and pollutes the environment despite the fact that the filtration sediment contains up to $80 \%$ of calcium salts, organic and mineral substances. It is also used as a feed additive [15]. The North Caucasian Scientific Research Institute of Sugar Beet and Sugar developed a technology that makes it possible to produce natural beet syrup and dietary fiber, which can be successfully used in other sectors of the national economy.

Modern equipment can squeeze the filter cake up to $70 \%$ of dry matter, after which it can be dried. It can be packaged and sold, or fired in special ovens until calcium oxide and $\mathrm{CO}_{2}$ form.

The filter cake, which contains calcium salts (up to $80 \%$ ) and organic and mineral substances can be used as a feed additive. A few decades ago, the Russian Research Institute of the Sugar Industry developed a technology for using filter cake as a feed additive. The North Caucasian Scientific Research Institute of Sugar Beet and Sugar developed a technology for processing sugar beet, which makes it possible to produce natural beet syrup and dietary fiber.

Beet sugar production is not limited to solid and liquid waste. It is also a source of dust and gaseous waste (dust, carbon dioxide, ammonia, etc.).

In the 21 st century, when the level of mechanization of harvesting and loading and unloading operations has improved, there is an increase in damage to beets and an increase in the amount of scrap (debris) and tailings. A small part of them is used as fodder along with pulp, and the rest is thrown into dumps.

A large amount of wastewater (up to $350 \%$ of the mass of processed beets) is discharged into the filtration fields, which requires fresh water, which is in short supply in many enterprises [15].

A whole range of measures are used to improve the technology of water management at processing enterprises. They can reduce the technogenic impact on the environment.

Calculations show that the science-based water management can decrease the consumption of fresh water and the volume of wastewater more than 10 times. The elimination of shortcomings in water use systems can save financial resources.

The filter cake is produced when purifying the diffusion juice. It contains up to $2 \%$ (of dry matter) of sucrose, $1.7 \%$ of pectin substances, about $15 \%$ of organic substances, $79-80 \%$ of calcium carbonate, and $50 \%$ of moisture. However, the use of the filter cake in the production cycle is $20 \%$. The sludge, diluted fivefold, is taken out to the filtration fields, where it is mixed with other wastewater. Sediment settles in dumps, occupies significant land areas, which are excluded from the land management process. In addition, the sediment can be washed into rivers by spring waters, which pollute them, and factories dump untreated water into the reservoirs.

A significant part of the land area occupied by filtration fields is due to the fact that processing facilities do not meet modern requirements. In general, less than half of the sediment is removed from the filtration fields.
After natural drying, zealous owners use it as an alkalizing agent for acidic soils.

Agricultural enterprises use defecate - a valuable fertilizer that contains lime, which is used for soil deoxidation. If it is applied for beet production at the rate of 16-25 t / ha, it can increase beet yield by 2.5-3.5 t/ ha.

With the intensification of the processing of raw materials, sugar production is "saturated" with new technologies that reduce the amount of waste. Increasing the role of secondary resources as raw materials for the production of new products makes it possible to develop the waste-free production technology. Sugar factories have to process sugar beets to produce valuable food and feed products.

Beet tops have a high feed value. $100 \mathrm{~kg}$ of this product contains $1.5-1.7 \mathrm{~kg}$ of digestible protein. In terms of protein and fodder units, the tops obtained from 1 hectare of beet crops can yield as much as 1 hectare of clover. The tops contain $5-6 \%$ of sugar, as well as a significant amount of fats, vitamins, calcium, phosphorus, manganese, copper, iron, zinc and other organic compounds that increase its nutritional value.

One of the main by-products of sugar production is bagasse. It is leached shavings of root crops, which remain after the extraction of sugar. Pulp is a valuable feed for cattle. It is used raw and dried. After squeezing out the water, dry pulp contains $15-18 \%$ of dry matter, $1.3 \%$ of crude protein, $0.1 \%$ of crude fat, $9.9 \%$ of nitrogen-free extractives, $3 \%$ of fiber, $0.7 \%$ of ash, $0.4-$ $1.0 \%$ of sugar. One ton of raw pulp contains up to 80 feed units, one ton of dry pulp contains up to 850 feed. Units. Its feed value is equal to the one in concentrated feed [29].

In the pre-reform period, near sugar factories in the Central Black Earth Region, there were specialized meat and dairy and pig farms. They received cheap products beef, pork and milk. An example is Belgorod region: nine specialized farms, which were located near the sugar factories, fed animals with pulp (64\%), concentrates $(20 \%)$, roughage $(5-7 \%)$. The average daily weight gain was more than one kilogram [3].

Currently, agricultural enterprises use only $30-35 \%$ of bagasse for animal feed. About $2.5 \%$ of it is dried, and the quality of pulp is poor. Pulp is dried at $600-8000 \mathrm{C}$ which destroys useful substances. Moreover, the final product is contaminated with dust and harmful substances generated during the incomplete combustion of fuel. At the same time, if the pulp is properly dried (at a temperature of no more than $1200 \mathrm{C}$ ), its chemical composition is almost equivalent to its fresh composition and can be equated in value to wheat and rye bran.

It is advisable to press the bagasse. This reduces the volume of pumping. Moreover, pulp losses do not increase; but the productivity of the diffusion apparatus increases; the fuel consumption can be reduced.

The fodder value increases when using additives, which make it possible to produce dried pulp - molasses, amide, amidomineral, vinasse. High-quality dried pulp will be in demand in other countries.

Currently, only $10 \%$ of the capacities of pulp drying plants available are used due to a large amount of fuel consumed when drying the bagasse and high wear of the 
equipment. The rest of the pulp turns sour in the factory storages. It loses about $50 \%$ of its fodder value, and another waste is formed - pulp water.

Pectin and pectin concentrates can be obtained from dried pulp. However, in Russia they are not produced on an industrial scale, although a number of industries need them. Pectin is imported. Due to its properties (gelling), pectin is a substance used in the production of food products, including those with prophylactic and therapeutic purposes. It is used in the production of confectionery, jams, jams, jellies, fruit drinks, juices, and mayonnaise. Pectin and pectin concentrates are also used by the dairy and canning industry and medicine as prophylactic and therapeutic agents.

It is necessary to develop a cost-effective technology for the production of pectin substances.

The most important by-product of sugar production is molasses. It is a source of valuable food and fodder. It is an intercrystalline solution separated during the centrifugation of the massecuite of the last crystallization.

Treacle (molasses) is a beet processed product, which is obtained after removing crystallized sugar from the solution. Molasses contains $58-60 \%$ of sugar, $13-14 \%$ of organic nitrogenous substances, $8 \%$ of non-sugar, $3 \%$ of pectin, $15 \%$ of nitrogen-free extractive substances. It is $4-6 \%$ of the weight of processed beets. Each kilogram contains $0.75-0.85$ feed units, $0.045 \mathrm{~kg}$ of which is digestible protein [30]. It can be used to produce 25 types of products that are used by the food, chemical, and perfume industries (yeast, alcohols, organic acids) [31]. Alcohol, glycerin, nutritional yeast, lactic, citric and glutamic acids, pectin glue and other products are produced from molasses. With the appropriate equipment, sugar can be extracted from molasses [32].

Many valuable components are concentrated in molasses. With a content of up to $80 \%$ of dry substances, it contains up to $50 \%$ of sucrose and $30 \%$ of non-sugars, including a significant amount of valuable amino acids and metal cations, anions of carbonic, sulfuric and phosphoric acids.

Molasses that contains many useful substances is used as an additive to feed (when enriching dried pulp). In other industries, it is used in the production of alcohol, food acids, yeast, lysine, fertilizers and other products. Molasses is one of the few products whose involvement in the economic turnover is $100 \%$.

Along with the direct use for livestock feed, citric acid and raw alcohol can be produced from molasses. In the production of citric acid, gypsum sludge as a waste product is used in the construction industry.

The regional structure of the secondary processing of beet sugar production wastes is shown in Fig. 1.

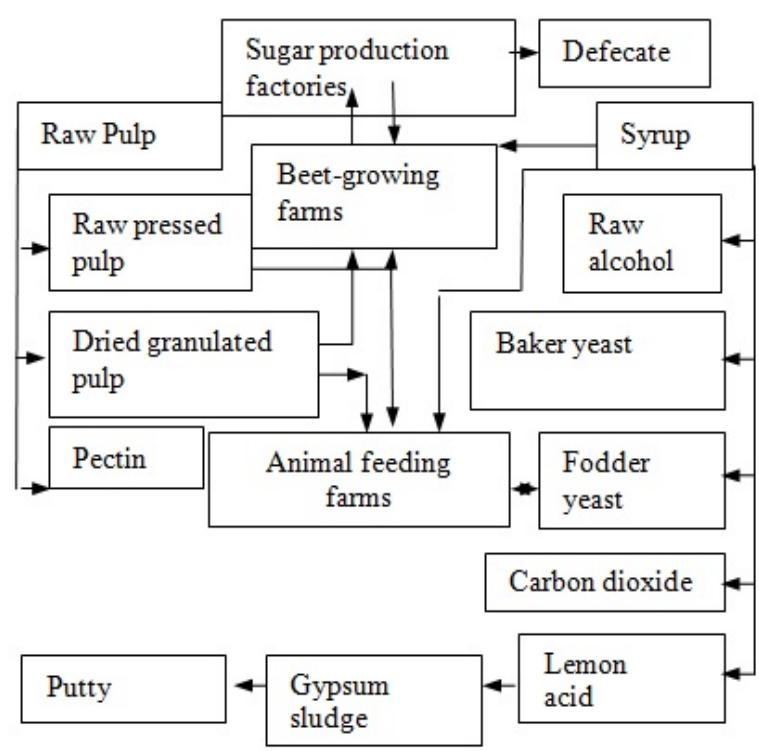

Fig. 1. The regional structure of the secondary processing of sugar beet waste.

\section{Conclusion}

It was revealed that in order to increase the efficiency of sugar beet production, it is necessary to use innovative technologies. It is necessary to implement resourcesaving, environmentally friendly technologies and process beet production waste.

In the beet-growing regions of Russia, it is expedient for each sugar factory to process bagasse and molasses and choose the most effective secondary processing methods. Some factories can produce baker's yeast and citric acid (e.g., Lgov sugar plant), concluding contracts with other related enterprises on the supply of molasses; other factories can produce raw alcohol or carbon dioxide; factories located near livestock feed farms can conclude long-term contracts on the supply of raw pressed and dried pulp (Figure 1).

\section{References}

1. N. Brar, B. Dhillon, K.S. Saini, P. Sharma Agricultural Reviews. 36, 184. (2015).

2. S.M. Hoseyni, H. Najafi, B. Sani, H. Mozafari, Applied Ecology and Environmental Research. 16, (2018)

3. A.T. Kalinin, A.A. Kalinin, Saharnaya svekla, 7, 5-7 (2002)

4. M. E. Kaminskaya, Materials of the scientific and practical conference on the topic "Scientific foundations of increasing the technical level of sugar beet production", 30-31 (1993)

5. V.I. Pyrkin, Sugar beet E 5, Integration processes in the sugar beet complex of Ukraine. 2-4 (1998)

6. G.N. Agrios, Plant Pathology. 2nd ed. (Academic Press, New York 1978)

7. M. Albert, X. Belastegui-Macadam, M. Bleischwitz, R. Kaldenhoff, Cuscuta spp: 
Parasitic Plants in the Spotlight of Plant Physiology, Economy, and Ecology., 267-277 (2008)

8. A. P. Draycott Sugar Beet (Wiley, New York 2008)

9. K. Khaksar, M.A. Noghabi, H.H. Sharifabad, E. Majidi, G. Normohammadi, Crop Research, E 52, 970-4884 (2017)

10. S. Izadi Mansourian, E. Darbandi, M. H. Rashed Mohassel, M. Rastgo, H. Kanouni Crop Protection 93, 43-51 (2016)

11. F. Meighani, N. Nezamabadi, M. Karaminejad, N. Jafarzadeh, Journal of Weed Science 12. 199209 (2017)

12. R.L. Zimdahl, Weed-Crop Competition: A Review. (International Plant Protection Centre, Oregon State University, Corvallis, 1980)

13. V. Nechiporenko, Master. E 11-12, 16 (1993)

14. I.T. Kryachkov, A.V. Mikhilev, Economic mechanism of management in an agricultural enterprise and the conditions for its effective functioning, (Kursk: KSAA, 2003)

15. M.A. Redchenko, E.A. Sarafankina, XXI century: the results of the past and the problems of the present plus. 1 (45), 108-111 (2019)

16. M.V. Kopylov, I.S. Naumchenko, I.N. Bolgova, E.Yu. Zheltoukhova, N.G. Mukhortov, Polzunovsky Vestnik, 7-11 (2019)

17. A.M. Chernikov, G.F. Kaplunov, Yu.S. Baglikova, Sugar, 28-29 (2019)

18. E.S. Nikolaeva, Collection of scientific articles of the 7th International Youth Scientific Conference, 321-325 (2019)

19. R.E. Mansurov, Agrarian Bulletin of the Upper Volga, (26) 113-121 (2019)

20. L.A. Sabetova, M.V. Devin, Technologies of the food and processing industry of the agroindustrial complex - healthy food products (19), 132-141 (2017)

21. S.M.Tokenova, Problems of AgriMarket 4, 169174 (2020)

22. L.V. Nakova, Materials of the international scientific and practical conference, Resourcesaving technologies in the agro-industrial complex of Russia, 578-582 (2018)

23. N.G. Kulneva, L.N. Putilina, N.A. Lazutina, Sugar beet, 32-36 (2019)

24. R.E. Mansurov, Sugar beet, 34-38 (2019)

25. N.V. Bezler, I.N. Kholopkin, Sugar beet, 23-30 (2017)

26. M.V. Sidak, Sugar beet, 6-14 (2019)

27. I.Y. Pigorev, I.P. Saltyk, I.I. Stepkina, Y.I. Bolokhontseva, Research Journal of Pharmaceutical, Biological and Chemical Sciences, 5, 1423-1428 (2014)

28. M. D. Sushkov, Sugar beet, 10,10-11 (2000)

29. V.V. Spichak, Materials of the scientific-practical conference Kursk, Environmental problems of sugar beet production: present and future, 49-53 (2003)

30. N.N. Zuev, Sugar beet, 4, 22-29 (1992)

31. O.I. Kapitonova, Sugar beet 2-4 (1997)
32. E.V. Ivanov, Sugar beet, 10, $2-7$ (2020) 